\title{
TOWARDS A NEW STRATEGY FOR ORGANIC MILK MARKETING IN HUNGARY
}

\author{
V. Szente*, O. Szigeti, Zs. Polereczki, Á. Varga and Z. SzakÁly \\ Department of Marketing and Trade, Faculty of Economics, Kaposvár University, \\ 7400 Kaposvár, Guba Sándor út 40. Hungary
}

(Received: 20 September 2011; accepted: 2 April 2014)

\begin{abstract}
In Hungary, organic food market has both demand and supply oriented aspects: several times not necessary products are distributed, while the selection and volume of certain products are not satisfactory. Thus, our aim was to develop a coordinated benchmark strategy to increase the trade of organic products. To get more details on the Hungarian organic milk market, we conducted professional deep interviews and simultaneously applied the "mystery shopping" method. Nowadays, the market of organic milk and dairy products is slowly increasing in Hungary, however, there is no available statistical data. In the selection there are mostly Hungarian originated products, but some yoghurt, milk, and butter assortments are imported. Partial responsibility belongs to small sale shops' habit of risk-avoidance. Without a proper selection of products, stores are unable to satisfy consumers' needs; thus they focus on pushing certain products to increase demand. According to our results, 'low price category', 'local/regional product', and 'prestige product' strategies with attached in-store marketing elements are able to reverse the effects of an unfavourable marketing process.
\end{abstract}

Keywords: organic milk, consumer, retail, benchmark strategy, position

The market of organic products is quite small in Hungary. However, based on its development potential it has strategic importance (SZAKÁLY, 2004). According to GFK Hungária (2005) lifestyle survey, about $65 \%$ of the Hungarians consider organic food the ideal nutriment of future. Researches of GERWIN (1998) and PANYOR (2007) show that $60 \%$ of the consumers have bought organic food in Hungary. In the research of SzENTE (2009), first the interviewers made the consumers familiar with the term and main features of organic foods. They asked the consumers questions only after this. It turned out that the majority $(59.2 \%, 710$ persons from 1200) have never bought such a product. The most frequently chosen products were fruit and vegetables $(14.4 \%)$, milk and dairy products $(6.9 \%)$, and bakery products $(3.4 \%)$. According to the results, a significant part of the consumers (40.1\%) is willing to pay a higher price for organic products. The reasons for paying premium price are mainly to protect their health and to avoid risks of diseases.

Milk production is a significant field of organic farming all over the world (HАMm et al., 2002; SAнOTA, 2009; ZaGATA, 2012; SсHAACK, 2013). The situation is the same in Hungary. Consumer demand for staple foods - especially for organic milk - has especially increased (Szente, 2009). On the basis of the study done by Nielsen (2009) ( $\mathrm{N}=500)$, it can be stated that in $200738 \%$ of the Hungarian consumers had already bought organic milk or dairy products. According to a previous study with the same sample size, this proportion was $16.6 \%$, but consistent customers were quite rare (1.6\%) in 2005 (SZENTE, 2009). Liquid milk is the most sought-after organic dairy product in Hungary and abroad, but the desire for

\footnotetext{
* To whom correspondence should be addressed. Phone: +36-82-505-800; e-mail: szente.viktoria@ke.hu
} 
flavoured yoghurt, cottage cheese, chocolate milk, and sour cream is also considerable (SzABÓ, 2007).

The favourable effects of organic milk on nutritional physiology play an important role in their decision; its higher conjugated linoleic acid (CLA), omega-3 fatty acid, and vitamin contents have been proven in a number of scientific studies (BERGAMO et al., 2003; NIELSEN et al., 2004; BAARs et al., 2005).

In Hungary, 124402 hectares of field space were devoted to producing organic foods in 2011 (Willer \& LeRnOUd, 2013). Crop production occupies a dominant place in the production structure. The rate of organic animal breeding is lower, and only a small area is currently devoted to non-grain vegetable and fruit production (BIOKONTROLl Hungária, 1998-2012).

Unfortunately, there is no reliable data in Hungary regarding organic food traffic; participations of sales channels are only estimated. Based on these estimates, the traffic of organic food in Hungary is about 30-35 million Euros. This amounts to less then $1 \%$ of the national food market traffic. The Hungarian organic food consumption level is even lower, only $0.5-1 \%$ of the total consumption (CZELler, 2009; GAUVRIT \& SCHAER, 2013). Hungarian organic food scarcely appears in retail; consumers can only buy imported, sometimes lower quality products. The market has problems in both supply and demand: they distribute products that are not needed, and certain desired products are absent.

Based on the observations above, there is a need for considerable developments in the marketing of organic milk. The aim of our research is to determine present domestic tendencies and to make strategic proposals to increase the market for organic milk and dairy products. In order to reach our aims we have decided to approach from the supply orientation: we have measured both the sellers' (including manufacturers with direct sale) and consumers' side.

\section{Materials and methods}

In our research, as part of the qualitative data collection, we conducted in-depth interviews. This method has a very exploratory nature, seeking the answers to open-ended ("why") questions about reasons, motivations, and opinions. The speciality of this method is to investigate deeply the reasons, motivations, and opinions that shape the target group's behaviour and preferences (MALHOTRA, 2008). Interviews were conducted with help of a guide. We contacted the retailers by telephone, based on the judgment. After that, we sent them the questionnaire draft and we scheduled a meeting with them.

During research we visited retail shops. We interviewed CEOs (Chief Executive Officers) or persons responsible for acquisition in hyper- and supermarkets (4 pieces), organic shops and drug-stores (4 pieces). We also interviewed organic product producers who sell directly to consumers (4 pieces). Usually they sell their products in farmers' markets, via mail-order, or in their own farm shop. Eventually 12 in-depth interviews were recorded. (2 CEOs of drug-stores did not accept our request.) The draft of the in-depth interviews contained 23 questions regarding 4 main topics: basic data, unique elements of acquisition, insider profiling of the specific shop, and selling.

Simultaneously with the in-depth interviews, we observed selected shopping locations regularly (every 4 month from September 2010 to August 2011) with "mystery shopping." Mystery shopping is a technique increasingly used in service organizations to measure 
intangible service experiences (FORD et al., 2011), such as popular in-store marketing applications in commerce. In a mystery shopping study the front-line operations of a business are evaluated by an anonymous trained observer (FINN \& KAYANDE, 1999). In our research mystery shoppers (sometimes also referred to as secret, phantom, or anonymous consumer shoppers) visited the selected retail shops incognito, where they recorded their experiences in an observation sheet. Our sample contained 2 hypermarkets, 2 supermarkets, 2 drugstores, 4 organic shops, and 4 direct sale points. (Same shops and chains, where the interviews were conducted, were in the sample.) In this form of quantitative research, we aimed for a systematic record of information about the shopping place without announcing our presence or intentions. With this method we could record data without influencing workers. This method also allowed us to gain information from consumers' perspectives about traffic, elements of price, and communication strategies in different sales channels.

The applied observation sheet contained 6 different topics: general points of view, details of the shopping space, product placement, merchandising, promotional tools, and organic product placements. In these categories we selected 44 criteria for evaluating the stores. Additionally, we sketched every shop, indicating the exact locations of organic products, and we took pictures of the shelves' appearance. With this method we received a precise picture about sale specialities and changes of organic products within a year.

The surveying was nationwide: we reached the representatives of the national/ international companies in Budapest, while during the selection of other participants, we aimed for equal regional dispersion. In the article we processed only data that directly pertains to organic milk and dairy products sale.

\section{Results and discussion}

\subsection{Purchasing strategies of organic milk and dairy products - results of in-depth interviews}

Organic milk and dairy products are available from supermarkets and hypermarkets, special organic stores, or directly from the farmers. As demand has increased, imported organic milk (mainly UHT) and cheese have appeared on the retail chains' shelves, forcing Hungarian producers and processors into a fierce competition. However, the rate of imported products shows a decline in the last few years.

The share of organic milk and dairy products is still lower than $1 \%$ of all such products sold, despite favourable figures from consumer surveys. All interviewed small independent retailers agree that this rate is favourable compared to other organic product categories. Only baby foods and, in some specialized organic shops, cereals and grain products are consumed at higher rate. Naturally, the distribution is different for direct retailers. Here, typically, the consumer can get dairy products from $100 \%$ pure organic sources. However, at one examined hypermarket chain, only $20-25 \%$ of the UHT milk and only $8 \%$ of the fresh milk was organic. The proportion of organic-sourced milk consumed increased 3-4\% in the period of JanuaryMay 2009, while the demand in other categories stagnated due to the economic crisis. However, interviewed small retailers in the second half of 2010 reported a regression in organic milk sales.

Another important factor to consider when trying to increase consumption is the product's price. The consumption price of organic products is usually $10-20 \%$ higher than the price of conventional foods in those countries with advanced organic food markets. But, 
these markets also experience periods in which this difference in price shrinks to negligible levels. In line of the findings these seemingly good consumption conditions have their own pitfalls: German consumers refused to buy organic potatoes sold in discount shops, because the prices were so low that they did not believe that an authentically organic product could be sold at such a price (Gross, 2006). But these discount shops continued to be the leading potato vendors after they raised the potatoes' prices by 26\% (Michels \& BIEN, 2009).

In Hungarian hyper- and supermarkets and in organic shops, the applied mark-up for organic products is $50-100 \%$. The interviewed vendors justify this hefty mark-up by citing the increased risk of products expiring on the shelves and the increased frequency of substandard goods among organic products. As a result of this mark-up, consumers often pay $30 \%$ or, more likely, $50 \%$ more than they would for conventional dairy products. According to the results of our research, small vendors favour stocking organic dairy products, especially when their domestic origin is certified. If it is economically feasible, they try to market domestic products at lower prices than imported ones. In their considerations the most important criteria is the saleability of a product: its price and value rate and its organic certification. Because of the exceptional nature of these products, they are scarcely found in both hypermarkets and small shops. Consumers most frequently encounter organic products in the form of cheese directly purchased from the producer, just as in the case of organic meat products.

The examined retail chains think that selling of organic food is important, but they are reluctant to give up their current income rate, and they are not interested in sharing selling risk. Their solution is to increase the selection of their own in-house brand, but these products are always imported. They are not afraid of losing current consumers who prefer organic products, because they have large local customer-bases. Within this environment, consumers remain loyal to the specific shop, but their trust decreases. Two different reactions occur in special stores. The first is - just as done by the chains- to decrease selection, keeping only the reliable and low-risk organic products. The other option is "escaping forward," an approach in which they serve consumers deliberately and with target-group oriented marketing strategy.

In this latter approach, the retailers give discounts to regular customers, constantly assist them, and try to create an intimate atmosphere in the store. This is a remunerative technique for successful direct retailers. In these cases retailers are able to resell nearly all of their stock because they need not charge customers a significant mark-up. A further advantage is the direct contact with consumers, which enables a faster reaction to their needs and an increasing level of consumer-trust. Because of this, shops employing this approach did not experience decline in customer traffic and have thus been able to increase their selection.

\subsection{Judgement of milk and dairy products' placement through the method of "mystery shopping"}

During the first two observations of the super- and hypermarkets, there was a selection of fresh and UHT milk, flavoured and natural yoghurt, chocolate milk, cheeses, sour cream, cottage cheese, and butter. However, at the time of the third observation, the chocolate milk, sour cream, and cottage cheese had disappeared from the shelves in all but one hypermarket. Also, due to reduced shelf size, the selection of cheese and milk became narrower. Furthermore, the dominance of in-house brands was noticeable: yoghurt and cheese were only available in the chain's private label. In organic stores the rate of UHT organic milk and yoghurt was about one third; the rest of the selection was soya and lactose-free milk. We did not find any change here within the examined period. The selection of direct retailers also 
changed a bit: instead of fresh products, special cheese selection took a leading part; more varieties of well-ripened cheese with long shelf-life were available, which indicates increasing selling safety.

Organic dairy products are commonly kept apart from regular dairy products on separated shelves - in some stores even in separate fridges. We found exception to this only in 2 hypermarkets, where organic UHT milks were mixed with conventional UHT milks. As indicated by the previous chapter, the higher rate-of-sale is not surprising according to other studies that confirm it is important for consumers to compare these products (primarily based on brand and price), so it is easier for them to find the desired organic food (Hempfling, 2004). Our observations show that only soya-based specialities designed for lactose-sensitive persons were displayed on the same shelf as organic milks. The rates of organic milk and dairy products were between 3 and $6 \%$, an increase over the last observation, which showed a rate between 1 and $3 \%$. Another favourable change is the decreasing rate of imported products: an initially observed $50 \%$ rate had shrunk to $10-20 \%$ by the last observation.

When considering impulse-shopping, certain elements have greatly increased importance: store layout, interior design, quality of equipment, and cleanliness. In the examined stores the selling area was clear, but the atmosphere and equipment were simple or functional with little consideration for aesthetics. Only two stores (a hypermarket and a drugstore) used shelves with wood elements to display organic products. In neither case were organic milk and dairy products displayed among natural elements. In organic stores we usually found wooden shelves and baskets and a homey atmosphere, but, compared to chain stores, these stores were less spacious and airy.

In terms of product placement, retail stores did not place organic dairy products in consumers' main avenues, and secondary placements were found only in the case of promotions. The observed stores usually provided a full shelf where every product that does not require cooling could be found. Besides that, organic products could be found in the fridges (milk and dairy products) or in the freezers (frozen vegetables, chestnuts cream). It is indicative of the size of selection that we could not find any brand represented in more than two slots on the shelf. Most brands have only one label facing the passing customer.

To increase the consumption rate of organic products, usually shelf labels or wobblers are used; other in-store elements (such as samples or floor stickers) are rare. The methods of stocking the shelves are not helping to increase consumption rate: on several occasions we saw empty or overcrowded shelves in hyper- or supermarkets and in organic stores.

\section{Conclusions}

Research into consumption shows there is an increase in demand. But the risk-avoidance and the acquisition habits of some great wholesale stores and organic stores have brought about a decrease in traffic and a narrower selection of organic milk and dairy products. Market growth will be assured only when they rediscover their interest in selling organic products. Our results have proved that for a change it is necessary to apply segment marketing instruments. We suggest to retailers these strategies, which could be used built on one another:

- "Low price category": One strategy could be to provide organic products at a lower price to gain and keep price-sensitive consumers. It is highly important not to separate these products from conventional products. Consumers' attention could be attracted via shelf 
labels, wobblers, distinctive labels, free samples, and regular (but not exaggerated) discounts.

- "Local/regional product strategy": Another strategic solution is to sell fresh products from local/regional sources more frequently, which could help strengthen consumers trust and patriotism, beside providing multiple sources for inventory acquisition. The aim of in-store marketing in this case is to affirm the ethical behaviour of the retailer; the applied tools are source labels and a layout emphasizing freshness (appearance akin to that of farmers' markets and usage of natural materials). The staff has an important role, because they have to provide assistance to consumers in addition to continuously monitoring and restocking the shelves.

- "Prestige product strategy": The third strategy could help retailers keep or increase their market share. This approach involves increasing the selection of high quality (premium) organic products. The most important applied marketing tools here are product placement and experience. To achieve good results, organic products must be placed next to the main shopping avenues, and secondary placements are also necessary. It is advisable to create a home-like atmosphere with soft lighting and background music and to give customers the opportunity to sample the products. Guidance also has an important role here; it should focus on nutrition benefits and the unique qualities of different products.

This paper was supported by the Bolyai Research Scholarship of the Hungarian Academy of Sciences.

\section{References}

Baars, T., Adriannse, R., Huber, M. \& Wohles, J. (2005): Milchqualität und menschliche Gesundheit. Gibt es Unterschiede in der Erzeugung? (Quality of milk and human health. Is there a difference in production?) Lebendige Erde, 6, 1-6.

Bergamo, P., Fedele, E., Iannibelli, L. \& Marzillo, G. (2003): Fat-soluble vitamin contents and fatty acid composition in organic and conventional Italian dairy products. Food Chem., 82, 625-631.

Biokontroll Hungária Nonprofit Ltd. (1998-2012): Éves jelentések. (Yearly reports) Budapest.

Czeller G. (2009): Az ökológiai gazdálkodás helyzete a Dél-Dunántúli régióban. (Organic farming in the Transdanubian Region) Kaposvári Egyetem, Kaposvár.

FInN, A. \& KAYANDE, U. (1999): Unmasking a phantom: A psychometric assessment of mystery shopping. J. Retailing, 75(2), 195-217.

Ford, R.C., Latham, G.P. \& Lennox, G. (2011): Mystery shoppers: A new tool for coaching employee performance improvement. Organ. Dyn., 40, 157-164.

Gauvrit, L. \& Schaer, B. (2013): A glimpse on organic markets in Eastern Europe. Presentation on Biofach Nürnberg 2013.

GFK HungáRIa (2005): Közép- és Kelet-Európa fogyasztói. (Consumers of Central- and Eastern Europe) Available at http://hvg.hu/gazdasag.hazai/20051116genkezelt/page3.aspx (last accessed 12 January 2011).

Gerwin, D. (1998): Characteristics of the market for organic products. In: Organic market review: Observations and experiences from the Czech Republic, Hungary and Poland. PHARE research, 3.

Gross, D. (2006): Das Wachstum geht an den Betrieben vorbei. (The growth goes past the farms). Ökologie \& Landbau, 34(1), 25-27.

Hamm, U., Gronefeld, F. \& Halpin, D. (2002): Analysis of the European market for organic food. Organic Marketing Initiatives and Rural Development, OMIaRD, vol. 1, University of Wales, Aberystwyth, United Kingdom, pp. $1-135$.

Hempfling, G. (2004): Mit gezielten Massnahmen den Absatz erhöhen. (Increase sales with targeted measures) Ökologie \& Landbau, 32(3), 33-35. 
Nielsen, H., Lund-Nielsen, J. \& Skibsted, T.L. (2004): Higher antioxidant content in organic milk than in conventional milk due to feeding strategy. Darcof News available at www.darcof.dk/enews/sep04/milk.html (last accessed 2 April 2014).

Malhotra, N.K. (2008). Marketingkutatás. (Marketing research), Academic Publisher. 832 pages.

Michels P. \& Bien, B. (2009): Dynamik des Kaufverhatlens im Bio-Sortiment (Dynamics of consumer behavior in organic range). Presentation on Biofach Nürnberg 2009.

NieLSEN (2009): Zöldség, gyümölcs, tojás a legnépszerübb bioélelmiszer. (Vegetable, fruit, egg the most popular organic food) Available at http://www.hu.nielsen.com/news/20071213.shtml (last accessed 12 January 2011).

PANyoR, Á. (2007): A különleges élelmiszerek piacnövelési lehetöségei megkérdezések tükrében. (The possibilities to increase market-share of special foods in the mirror of questionnaires) $\mathrm{PhD}$ Dissertation, Budapesti Corvinus Egyetem, Budapest, pp. 1-112.

SchaAcK, D. (2013): News about the organic market in Germany 2012. Presentation on Biofach Nürnberg 2013.

SAhota, A. (2009): The global market for organic food and drink. -in: Willer, H. \& KLicher, L. (Eds) The world of organic agriculture: Statistics and emerging trends. FiBL-IFOAM-ITC Bonn, Frick and Geneva, pp. 59-64.

SzABÓ, A. (2007): Az ökotej- és tejtermékek piaci és gazdasági értékelése. (Market and economic analysis of organic milk and dairy products) PhD Dissertation, Kaposvári Egyetem, Kaposvár, pp. 4-52.

SZAKÁLY, S. (2004): Táplálkozási dilemmák és az élelmiszerek fejlesztésének világstratégiai irányai. (Consumption dilemmas and strategies in food-development). Élelmiszer, táplálkozás és marketing, 1(1-2), 15-24.

Szente, V. (2009): A bizalom megítélése az ökoélelmiszerek piacán. (Judgment of trust on the market of organic foods). Élelmiszer, táplálkozás és marketing, 6(1-2), 59-63.

Willer, H. \& Lernoud, J. (2013): The European market for organic food 2011. Presentation on Biofach Nürnberg 2013.

ZAGATA, L. (2012): Consumers' beliefs and behavioural intentions towards organic food. Evidence from the Czech Republic. Appetite, 59, 81-89. 